\title{
THE LONG-TERM METHOD OF THE URBAN PROJECT IN ITALY AND THE PARMA SCHOOL
}

\section{Carlo Quintelli}

If, as incurable users of historical categories, we were to adopt the period of the Italian Renaissance between the 15th and 16th centuries as a moment in which the culture of the modern project began to define its own interpretative theoretical status, and also its explicit subjectivity, we should immediately recognize the peculiar characterization in the dialectic between architecture and city. An Italian city understood as a material body that is no less than formal, symbolic, but also political and cultural, as its construction accompanies the processes of evolution of the society inhabiting it. And this gives rise to the aptitude for an architectural project that we define urban not so much or just because its field of application is the city but because it thinks and acts in an urban sense, making the city its own instrumental laboratory between interpretation and proposition. There is no need to cite the theoretical elaborations of Leon Battista Alberti which bring us back to the principles of a treatise that investigates architectural form in reciprocal analogy with urban construction in the concrete aspects of De Re Aedificatoria or the purely urban dialectic of the project between "principles, cities, architects" following Tafuri's historical introspection on the Renaissance (Tafuri 1992), with Filarete's visions that overcome ideality in favor of an experimentation of architecture as a typological urban mechanism, rather than the strategies of Leonardo's settlement design for a Metropolitan Milan with a territorial role. ${ }^{1}$ Raphael was concerned with the architecture of the ancient city not only in terms of forms but even as a material conservator ante litteram in his letter to Leone X, while in Venice a politically mediated contrast arose between the technical pragmatism of the Gothic city and the representative, as well as typological, innovation of a city with the modernity of classical expression, between the adaptive manner of Sansovino and the proto-modern radicality of Palladio. On the other hand, even when the architectural invention seems to focus entirely on itself as a monumental icon, as in Brunelleschi's dome, the entire city is reflected therein, starting from a cultural debate that involves it in the theater of the great vertical construction site up to the historical epilogue of a Vasarian corridor which, on the contrary, horizontally unravels in the body of the urban morphology in the synthesis of scale between architecture and city. And so in hundreds, if not thousands, of cases, this is in fact the reality of the urban tradition in the Italian context, made up more than by villages, as 
Braudel would say for France, of medium, small, and very small stone cities of precise garrison shapes of a territoriality with a high designed rate of anthropization, starting with the Roman matrix of the division of lands. Compared to the Europe beyond the Alps with a still predominantly wooden city formed through opportunistic logics of the whole, the Italian one is more enunciated through an architecture increasingly structured on the planes of the constructed material as well as the design of ideal forms in a systemic key. Matter and form simultaneously obtainable from the archaeological quarries and from the relief of the ancient, where the responsibility of the project, between the figure of the building and the urban landscape, acquires extraordinary degrees of responsibility and, in direct proportion, of disciplinary knowledge. A modernity that is therefore inevitably linked to the protagonist role of the city and its architecture in history, according to a dialectic that in some ways has slowed down its most dynamic and transformative expression in the last two centuries; for example, that which originated from the production processes of industrialization and its related sociocultural phenomena. In this sense, it appears exemplary that the rhetoric of the classicist modernism of fascism in Italy has applied to cities or pieces of cities rather than single architectures or that the idealized memory of the city is filigree to the abstract rationalism of Terragni or evocative thought of Moretti and, even after the postwar period, that the founding program of a factory is not limited to its own productive enclosure but becomes a city itself, alongside the historical one, as in Olivetti's Ivrea.

Community, in the case of the political and social thought of Adriano Olivetti, and continuity in the case of Casabella, the magazine directed by Rogers, constitute two assonant and in some respects complementary terms in the research of role in the architectural and urban design of postwar Italy. The first when experimenting with the evolution of the paternalistic form of the industrial settlement through the logics of collectivist organization in the community sense of the city. The second when critiquing internationalist modernism starting from the role of memory and environmental preexistences in the identity construction of the city to which the architectural project contributes. Starting points and paths for developing a modern view of an interpretative, phenomenological, non-dogmatic, and modeling nature. The humanistic and historical data, the analysis of phenomena, and an idea of the city and architecture for a renewed but conscious society are intertwined.

Admitting even a minimal validity to this interpretation and wanting to judge the role of the project on the threshold of the Third Millennium with an eye to the 20th century, the Italian one could in some respects appear to be a rearguard architecture in that it has continued to look at the historical experience of the city, certainly stimulated by its dynamics but at the same time also held back by the connections with the urbanity of inertia, procedural customs, up to the identity legacy of tradition (including its falsifications). But if from the same threshold one instead focuses on the perspective of the current century, then the denoted urban dialectic that still affects a substantial part of the Italian architectural project seems to take on a new meaning with respect to emerging and highly relevant issues in the future scenario. Those that require leaving the objective, self-referencing dimension of architecture, with all the narcissistic and simulacral drifts that denote it, to offer alternatives to the transformation processes of the city in a neoliberal sense and to the technological dynamics functional thereto, increasingly developing the critical role of the project with respect to the collective needs of the inhabited contexts. A conscious planning, of a cognitive nature and with purposes of general interest, provided with interpretative tools before being assertive, and with a sensitivity suitable to compare itself with the physiology (functions and 
relational dynamics of urban life) as well as with the structure of the urban organism (that of form and figure no less than the material of the built city). A project urbanity understood above all in a cultural sense, without which it will be more difficult to properly orient the transformation of the city, including its conservation, before the scenarios of climate change, biological environmental criticalities, economic instability, an increasingly difficult dialectic of social balance, and the need for identity that continues to come from individuals and the communities to which they belong. A renewed dimension of the problems, unfortunately increasingly dragged into becoming emergencies up to the dystopian datum, that a project methodology created within the relationship with the city is certainly better able to deal with the right degree of design control, that which comes from historical experience and from the understanding of the complex nature of the processes in progress in regulating innovation, rational structures, and prospects for civil and, above all, general growth.

It goes without saying that the dialectic between architecture and city according to the urban material denoting the project, not only in a dimensional and phenomenological sense but also in an epistemic sense, implies a different degree of codification of the principles and models that guide the project technique a priori. In fact, it is in urban and territorial realities that we find a significant, even if not absolute, part of the contents and characteristics to be invested in the project's economy. Hence the consequence of a non-univocal technical device, which comes about between disciplinary deduction and phenomenological induction, outlined in the differences among cities, which in the Italian cultural and geographical context are as relevant as they are close together. The experience of the urban project defines more a method than a project methodology in these terms that, while maintaining the denotation of its contemporaneity, is able to actively involve the field of preexisting buildings, rediscovering meanings, reinforcing values, and introducing functionality and signs as innovative as they are congenial to the city in which they are located in the choral urban counterpoint. It is not a question of regional ideology or of local relativism or of eclectic drifts linked to contingency, but it is a question of design temperance that examines things themselves in their consistency, which defines categories that are not absolute, avoiding ideological, or worse still, stylistic dogmas, perhaps better to say communicational today, of an architecture that is always tempted to be fashionable.

The small and relatively new Faculty of Architecture of the University of Parma, founded in $1998^{2}$ starting from two main academic lines of reference, also fits into the urban prerogative that characterizes the long course of the culture of Italian architectural design. The first, that of Milan, represented by Ernesto Nathan Rogers since the 1950s through the magazine Casabella and some of his followers such as, in particular, Aldo Rossi and Guido Canella, but also, in general, by a cultural and professional Milanese context characterized by figures such as BBPR, Gardella, and Albini, to limit ourselves to the main ones in a panorama full of extraordinary personalities.

The second, even more articulated one in Venice is represented by Giuseppe Samonà and his school, the IUAV (Istituto Universitario di Architettura di Venezia), which since the postwar period has been an original case of a heteronomous school where Samonà's culturalist and humanistic conception has summoned different personalities of project culture. From Zevi, understood as a historian focused on operational criticism and therefore strongly committed to orienting design culture also in an international sense, to Scarpa, to the same Gardella and Albini themselves here in an academic capacity, not to mention Saverio Muratori, in an articulated but unitary application between the reasons of the architectural language and those of the city and the territory at least on a regional scale (Veneto and 
Friuli Venezia Giulia). A school experience that will see the figures of Luciano Semerani and Gianugo Polesello, Costantino Dardi and, through other paths, of Carlo Aymonino as animator of the Architecture Group as followers of Samonà. Last, also included in this vast field of school but in other ways autonomous, is Aldo Rossi. Well-identifiable personalities recognized also at an international level until the 1980s when, with the birth at the IUAV of the first Doctorate in Architectural Composition in Italy, the conditions of continuity but also of renewal of that school tradition were established. ${ }^{3}$ Similarly, in the last two decades of a contemporaneity closest to us, other figures and research lines animate those academic laboratories of experimental tradition, strengthening or in other ways ignoring their legacy.

Overall, it is a heritage of cognitive advances marked by a production of original and research-oriented nonfiction with urban architectures of extraordinary experimental quality, where the theoretical contribution often arises a posteriori from the built outcome or from high-level demonstrative competition projects according to that "utopia of reality" in which architecture and city put each other to the test of historical becoming. ${ }^{4}$ The panorama of reference points is vast and articulated by typological genres. Merely by way of example, for those belonging to the younger generation or to contexts far from the Italian one, I would mention the Velasca Tower of BBPR in Milan (1950-1958) as regards the relationship between architectural figuration and urban identity, to which they act as a choral counterpoint not only in the allusive relationship with the historic city, the Venetian Casa alle Zattere by Gardella (1958-1960) or the INA Palace by Albini in Parma (1950-1954). A relationship with history that is not rhetorical but of extraordinary interpretative (i.e., inventive) radicality on urban nature emerges in the "Novissime" project by Samonà created for the competition for the Sacca del Tronchetto in Venice (1964), in whose water square the "Teatro del Mondo" by Aldo Rossi (1980) would find a congenial home, and then descending along the Grand Canal to the "Ponte dell'Accademia" by Gianugo Polesello (1985) for the Architecture Biennale. And among the many competitions I would also mention the one closest to me for the reconstruction of the Paganini Theater in the urban space Pilotta in Parma (1964) where, between the autonomy of the monument's architecture and the search for its completed form from preexistence, Aldo Rossi and Carlo Aymonino face each other in a complementary way. Of no lesser scientific impact are the essayistic returns of relevant epistemological innovation, from Rossi's "The architecture of the city" (1966) to the research carried out on the typology-morphology relationship in project interpretation that emerges from the Venetian volume "The city of Padua" (1970) curated by Aymonino and written by many contributors. In other respects, the idea of the project as a strategic instrument capable of affecting the city structure in its metropolitan relations is concretized in that "great theater of the Milanese hinterland" created by the architectures of the public services of Guido Canella, ${ }^{5}$ among which the Civic Center of Pieve Emanuele emerges and in which the residential architecture understood as a piece of the city in the Gallaratese (1967-1970) built by Aymonino is also indirectly inserted. But the list would be too long and the exemplarity far more extensive in a cultural geographic as well as a generational sense than what this opportunity allows.

Starting from the school reference lines that I have briefly mentioned, the didactic and research nucleus of the University of Parma dedicated to the culture and practice of the compositional project - involving in particular myself as well as Enrico Prandi and, more recently, Marco Maretto, Carlo Gandolfi, and other younger graduate students, postdocs and students, the latter called to an education that recalls the experience of research - has been applying its own original path of experimentation for 20 years, articulated over time 
through the focus of some thematic nuclei and the development of disciplinary advancement tools based on the relationship between architecture and city.

The attention to the context of Parma first of all, as a place where the Faculty of Architecture belongs, understood as a research field in terms of analysis and applied architectural and urban project. A context immediately interpreted in its territorial dimension that is even more susceptible in this case, since it was formed through the marks of Via Emilia and a division of lands that geometrized a vast territory from Piacenza to Bologna in a matrix key, making Emilia architectural but with transversal ties toward the Ligurian-Tuscan and Lombard-Veneto sides. A territory where the consular road carries out its poleogenetic function, determining the current polycentric urban system. A linear city in fact, with an intermittent character between settled nuclei and the countryside, to which the project research for a renewed functionality and new architectural components could restore a peculiar notion of city and landscape: the one that we have called Cittaemilia with a new toponym. ${ }^{6}$

Within this theater of both territorial and urban applied research since 1987, there have been several occasions to test the architectural project as a contribution to the problems and potential of the Emilian settlement system. Through typological themes of a historical identity and civil nature such as for the theater in Parma, or on architectural types intended to interpret new role potentials of certain urban places starting from the motorway junctions, to the railway stations and the central areas in the contexts of Piacenza, Parma, Reggio Emilia, and Modena, aimed at configuring a synergistic systematicity between the cities. A project focus whose premise is the theme of the centric linearity of the ancient consular road, to be rediscovered as still being a factor of relationship and settlement identity today, on which to develop the redesign of the intermediate settlements between the capital cities in contrast to the growth of a speculative conurbation that tends to cancel the alternating character between the city and countryside of Via Emilia. ${ }^{7}$

Starting from a concept of environmental sustainability that envisages the principle of zeroing land consumption for settlement purposes and the enhancement of the compact city, according to a policy of building in the built area that entrusts the city with a primary civil task aimed at combating the disaggregating phenomena of social sprawl as well as a settlement one, specific school project research re-elaborates the theory of the city by parts through a methodology of both morphological and functional structuring of the city. A strategy of reconfiguration of the urban composite according to the logic of morphology hierarchization that involves the resources already present in the city: through condensers of public and private functions with collective value and relevant architectural and urban typologies, to be re-aggregated through the strengthening or creation of nuclei of centrality capable of catalyzing urban and social functionality in terms of critical mass, starting with the public and in any case collective functions. In this process of identification and characterization of urban centralities through targeted design interventions, the resource of the urban void plays a fundamental role, understood as an often inert resource and to be reevaluated in the economy of a compact city both in terms of built and open space for aggregation and public relations. A methodological path that takes the name Spinner 2013, within an action of the European research funding of the Emilia Romagna Region, ${ }^{8}$ which will also develop thanks to the contribution of doctoral research up to a more advanced configuration entitled: Urban regeneration technique through the structured densification of the system of centralities (TDSC).

An analytical design path that starts from the interpretation of the parts of the whole city to come to define, through different levels in a trans-scalar key (compact city - areas fields - centrality), the individual centralities to which to entrust functional, identity, and 
urban life roles on the scale of the neighborhood rather than the urban, metropolitan one, and also of a vast system in a polycentric key. In this process, the dimension of urban design is continuously related to that of architectural typology where the problem of forms, in addition to the aspects of continuous functional and fruitive innovation, is addressed on the level of the characters of the context, of an identity strengthening derived from the landscape and from the peculiarities through which the structure of the city's historical layout was created. In continuity with the Spinner research, the project research is currently focusing on those substantial arts of the urban fabric, interposed between the central nuclei, called in any case to collaborate in the redesign and widespread livability of the compact city. Always in the logic of the urban parts and according to the assumption of verifying the potential of city living in an aggregate and inclusive form, the experimentation adopts the urban block, or by merging the macro-block, as a morphologically circumscribed and identifiable particle to which to entrust the meaning of an urbanity strictly related to the conditions of residence in terms of services, spaces, mutation logic, and the social relationship of community value.

In many ways as a complement to the research on urban regeneration mentioned above, the University of Parma itself is involved as an area of project application, highlighting the potential of its own settlement, in this case articulated between the historic center, the hospital complex, and the suburban campus of sciences, as a system that questions itself and is capable of experimenting with the themes of the future city. The project involves a community
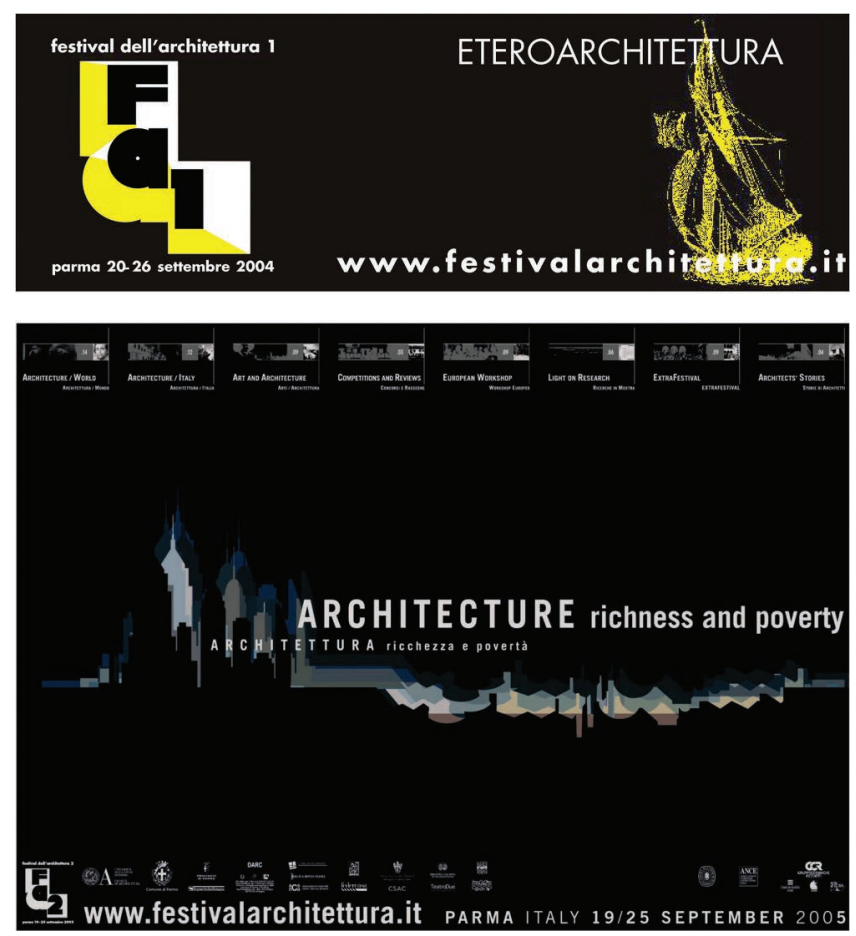

FIGURE 17.1 Above: Festival dell'Architettura 1 - Eteroarchitettura. Parma, September 20-26, 2004. Below: Festival dell'Architettura 2 - architecture, richness, and poverty. Parma, September 20-26, 2005. (CArchicittà - Festival dell'Architettura). 
understood as self-reflective, the university community composed of teachers, researchers, and students, since it is able to consider itself in the interdisciplinary key of scientific applications destined to fall within the experimental processes of the camp's urban transformation: from new types of buildings for collective purposes, services, and accommodations, to technologies aimed at energy containment and the use of renewables, public-private laboratories for innovative process and product research (starting from the agri-food calling of Parma within the context of the Food Valley), up to digital networks, environmental monitoring experiments, the theme of waste, and the qualification of urban green areas with a scientific approach regarding biodiversity. This also applies to other university sites of the historic city, focusing on the issues of management and enhancement of cultural heritage (including the project archive at the CSAC - Centro Studi e Archivio della Comunicazione) and on the redesign of the hospital typology in a more integrated logic between research and clinical activity, in a context

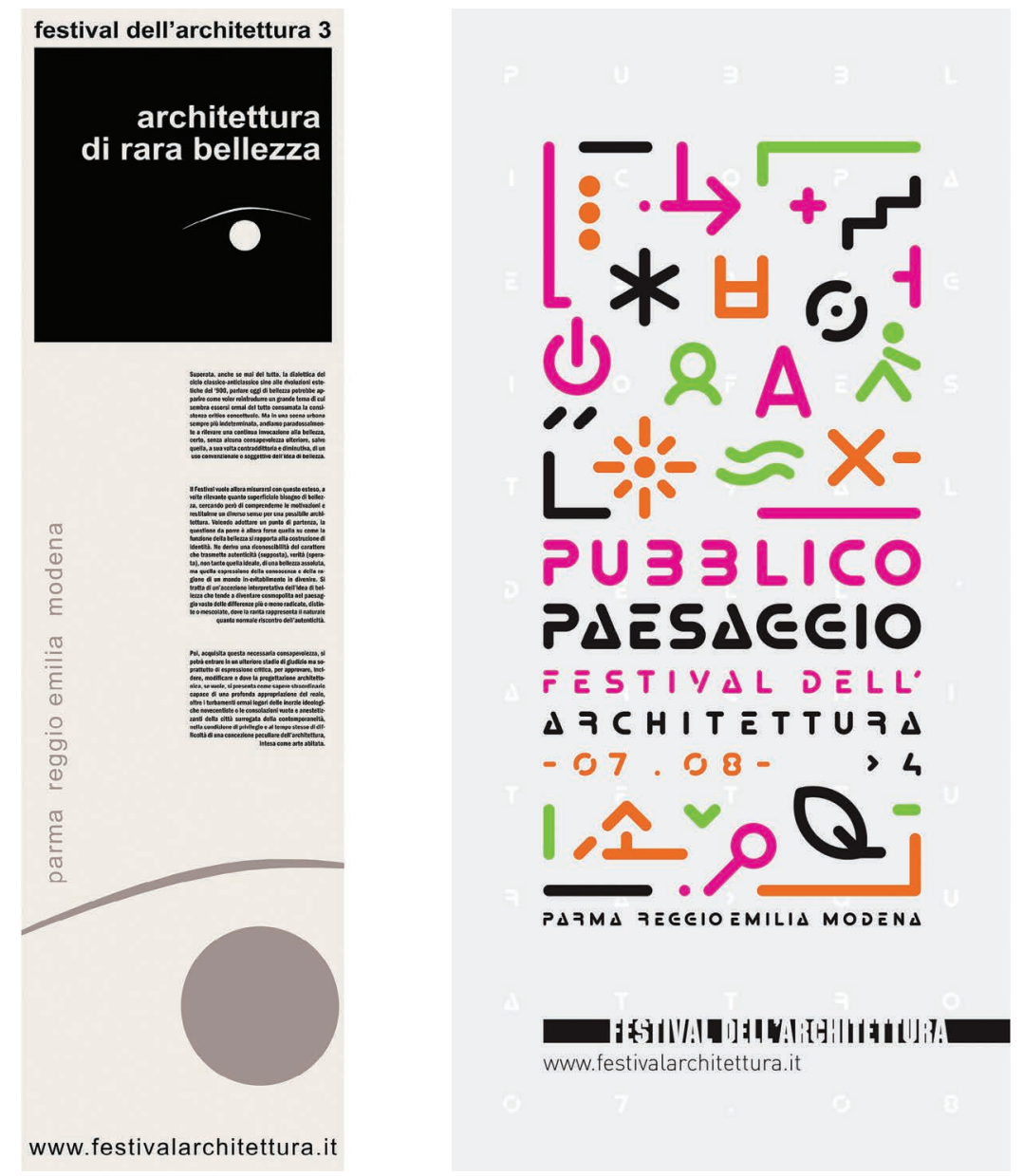

FIGURE 17.2 Left: Festival dell'Architettura 3-Architettura di rara bellezza. Parma, Reggio Emilia, Modena, October 23-29, 2006. Right: Festival dell'Architettura 4, 2007-2008, public landscape. Parma, Reggio Emilia, Modena, November 29 to December 14, 2007 and October 18 to November 9, 2008. (CArchicittà - Festival dell'Architettura). 


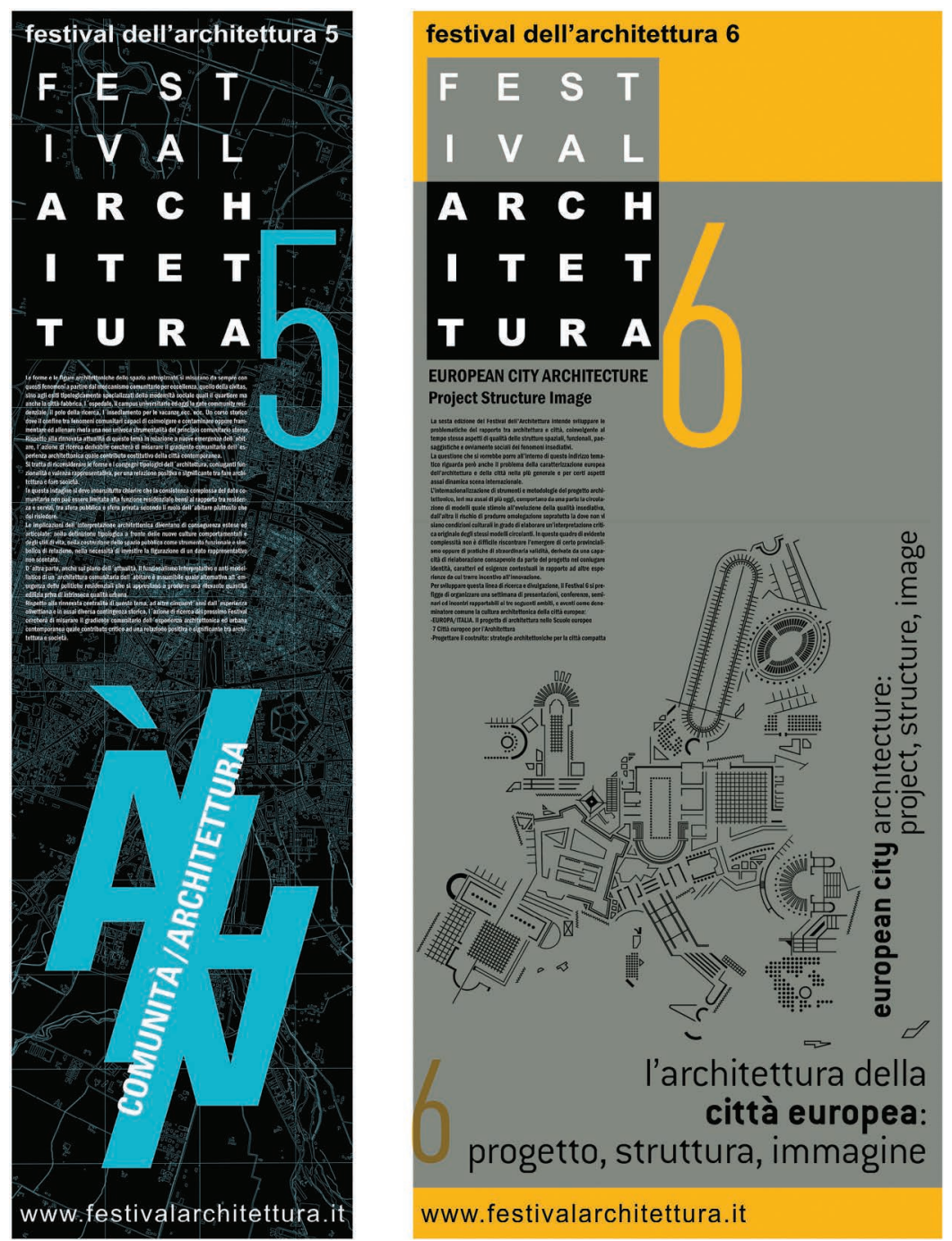

FIGURE 17.3 Left: Festival dell'Architettura 5, 2009-2010, community/architecture. Parma, Reggio Emilia, Modena, October/November 2009 and November 26 to December 12, 2010. Right: Festival dell'Architettura 6, 2011, European city architecture. Project, structure, image. Parma, Reggio Emilia, Modena, October 19-22, 2011. (C)Archicittà - Festival dell’Architettura).

of urban livability of the space for prevention as well as for cure. This is an articulated project of strategic value, called Mastercampus, on a city scale but with different intervention focuses in different places or university buildings, some also built, capable of defining an advanced settlement model and above all integrated with the reality of the host city. ${ }^{9}$

In the context of the School of Parma, attention has always been placed on the comparison and dissemination of university research on the themes of architectural and urban design, thus giving rise to numerous initiatives of international importance. A first phase 

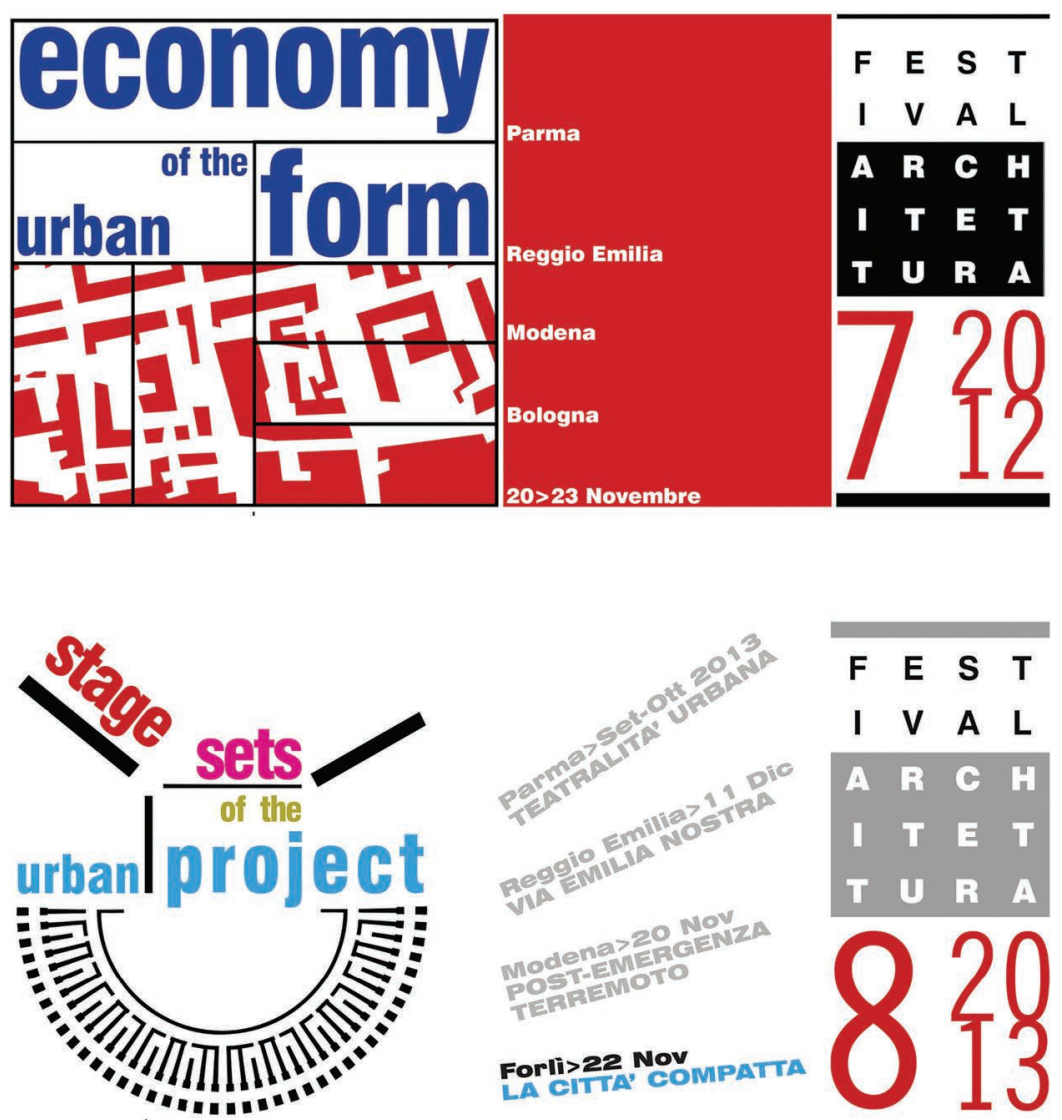

FIGURE 17.4 Above: Festival dell'Architettura 7, 2012, economy of the urban form. Parma, Reggio Emilia, Modena, Forlì, November 20-23, 2012. Below: Festival dell'Architettura 8, 2013, stage set of the urban project. Parma, Reggio Emilia, Modena, Bologna, September to December 2013. (CArchicittà - Festival dell'Architettura).

was the so-called summer architectural project seminars entitled "The City of the Theater" (1987, 1990, 1994) and to follow "Cittaemilia" (1998, 2000). Opportunities for discussion on the applied project with the participation of Italian architecture schools aimed at favoring a direct generational exchange between masters and also very young students. But it is with the organization of the Festival of Architecture, from 2004 to 2014, that a structure was created capable of promoting a cognitive activity and enhancing research on the architectural and urban project on an international scale, involving various universities of original research, enhancing professional studios and individual architects of still unknown quality, taking up themes of a historical nature and disciplinary tradition to be updated, exploring the most promising settlement and architectural expression phenomena in emerging countries and not least the critical issues in the so-called advanced countries, above all seeking to understand and ask questions about the effects of globalization on architecture and the city. Hundreds of exhibitions, conferences, workshops, seminars and also competitions, introductory courses to the discipline, and calls for research specifically solicited with respect 


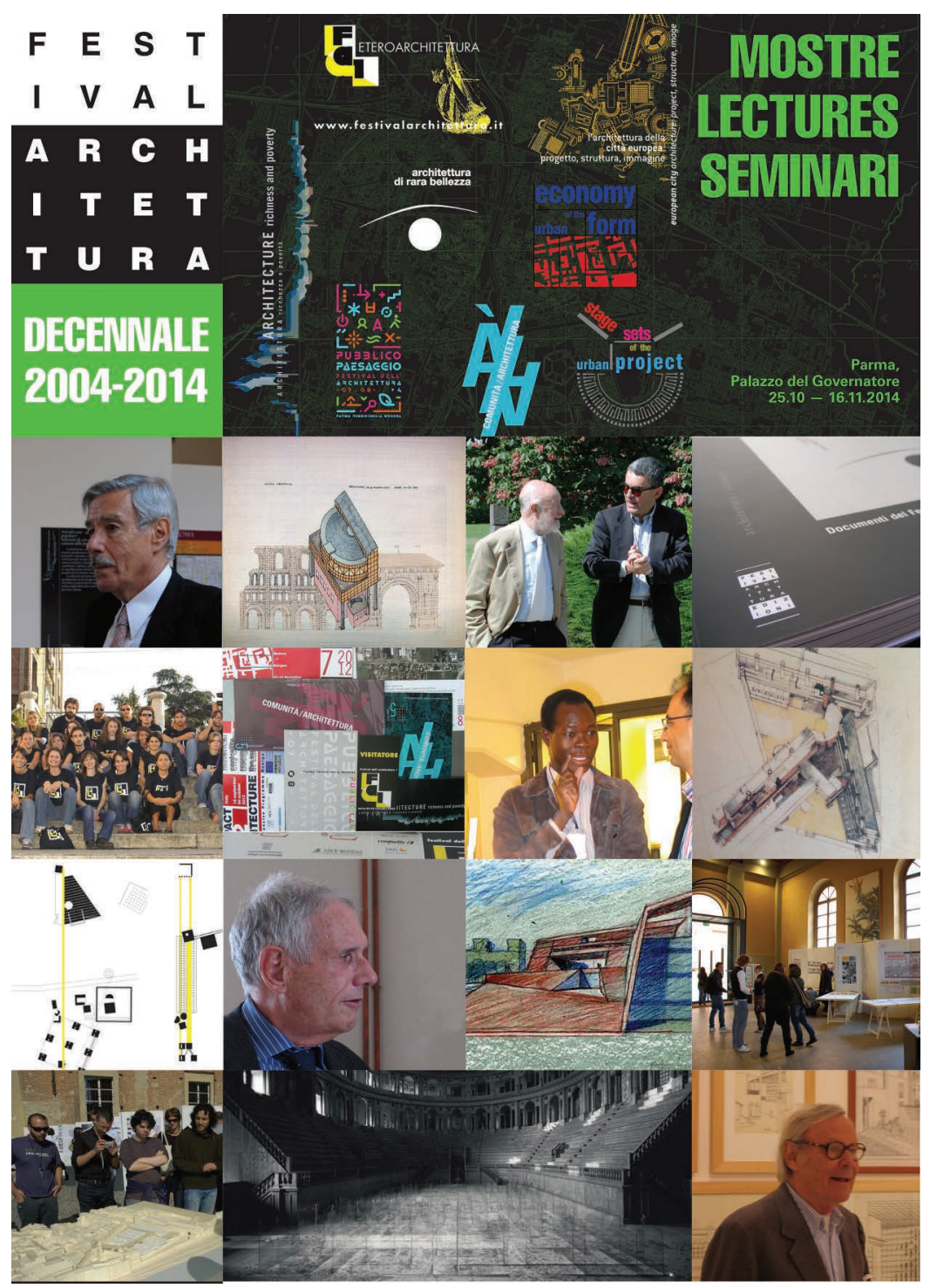

FIGURE 17.5 Festival dell'Architettura 2004-2014, ten years of the Festival of the Architecture. Parma, October 25 to November 16, 2014. (C)Archicittà-Festivaldell'Architettura).

to the theme that each edition of the festival focused on through problematically eloquent titles including "Architecture, richness and poverty," "Architecture of rare beauty," "Public landscape," "Community - Architecture," and "Economy of the urban form."10

The sixth edition of the festival in 2011 was entitled "The architecture of the European city: project, structure, image" (Amistadi and Prandi 2011) as if to foretell the development of a research that in recent years, also through the workshops of the Erasmus IP "The Europe Effect - An urban gate for the University Campus in Parma's Oltretorrente District" and "Compact City Architecture. Designing Centrality, Regenerating Suburbs"11 up to 
today with the "ArchéA" project, has seen growing interest in a project culture oriented to the European dimension of architecture and in particular through the typology of the average city, the one that has always distinguished the characterization of the most authentic territorial relations in a Europe of cities rather than nations (Figures 17.1-17.5).

\section{Notes}

1 Guido Canella and his school in particular cultivated a perspective of urban interpretation of architecture starting from the structural and exchange dynamics of the city in history. See Canella (1981).

2 The new Faculty of Architecture, promoted by Carlo Quintelli with the decisive scientific contribution of Guido Canella, saw the approval of the then-Academic Senate and the Magnificent Rector Nicola Occhiocupo of the University of Parma, as ratified by the Rector's Decree of September 22, 1998.

3 The Research Doctorate in Architectural Composition of IUAV, in consortium with the Polytechnic Institute of Milan and the University of Naples, had a Board of Professors composed of Emilio Battisti, Guido Canella, Alfredo (Fredi) Drugman, Giorgio Grassi, Gianugo Polesello, Aldo Rossi, Alberto Samonà, Luciano Semerani, Uberto Siola and with Francesco Tentori as coordinator. An area of confrontation between schools, with a prevalence of Venetian orientation, whose first cycle covered the three-year period 1983-1986. In the first setting of the doctorate, the theme of the transmissibility of the teaching of the Italian 20th-century masters assumed particular importance, giving rise to a series of lessons later collected in the book "Lezioni di progettazione. 10 maestri dell'architettura Italiana" (Montuori 1988).

4 In the mid-1960s, the climate of theoretical elaboration that characterized the Milanese and Venetian schools in the syncretism between teaching and research, through young teachers often involved in both academic fields, is clearly detectable through two exemplary publications: "L'utopia della realtà" (Rogers 1965) and "Teoria della progettazione architettonica" (Samonà 1968).

5 The quotation refers to the essay by A. Christofellis, 1976. Canella's attention to the Milanese context as a laboratory for experimenting a project epistemology based on the cognitive principle of typological and figurative characters as well as on the physiology of the city in its historical evolution in relation to the territory is quite demonstrative. In this regard, see, among others, the nonfiction production of the magazine Hinterland (1977-1985) and in a more general key of the magazine Zodiac (1989-2000), both directed by him.

6 The new toponym Cittaemilia was used for the first time in a summer seminar on architectural design held in Parma in 1998 and included in the book "CITTAEMILIA. Sperimentazioni architettoniche per un'idea di città" (Quintelli 2000). Among others, Quintelli (2002, 2012). In a context of extensive comparison on the type of linear city, see also Prandi (2016).

7 Several essays by C. Quintelli and collaborators on interpretative work and design research in the context of Emilia crossed by Via Emilia, including Quintelli (2001, 2005, 2006, 2014).

8 Research project presented in 2011 for the competitive call of the Emilia-Romagna Region within the European Social Fund with the title "Spinner 2013 - Progettare il costruito, nuovi modelli a qualità integrata per la città compatta. Politiche di rigenerazione e struttura delle centralità urbane nel contesto delle città dell'Emilia-Romagna" [Spinner 2013 - Designing the built, new integrated quality models for the compact city. Policies of regeneration and structure of urban centralities in the context of the cities of Emilia-Romagna]. For a more detailed illustration of the research methodology, see the essay by E. Prandi present in this volume.

9 A restitution of the scientific but also programming approach by C. Quintelli as pro-Rector of the Building, Infrastructure, and Urban Development Area of the University of Parma (20132017) can be found in the following publications: Quintelli $(2011,2017,2018)$.

10 The originality of the festival formula for the architectural field was indicated on the levels characterizing the university culture and the polycentric location of the event (based first in Parma and then also in Reggio Emilia and Modena) through the research of Guido Guerzoni of Bocconi University of Milan (Guerzoni 2008). Among the editorial spinoffs of the festival, the scientific open access e-journal FAMagazine. Research and Projects on Architecture and the City (ISSN 2039-0491) directed by Enrico Prandi is particularly active. 
11 Erasmus workshop held in Parma as part of the LLP (Lifelong Learning Program), respectively in 2012 with the participation of the architecture schools, as well as Parma, of Aachen, San Sebastian, Barcelona, Krakow, and in 2013 of those of Prague, Istanbul, Hamburg, and Nantes. See Prandi (2012, 2013).

\section{Bibliography}

Amistadi, L. and E. Prandi. (eds.). 2011. European City Architecture: Project Structure Image. Parma: FAEdizioni.

Aymonino, C., M. Brusatin, G. Fabbri, et al. (eds.). 1970. La città di Padova: saggio di analisi urbana. Roma: Officina, 1970.

Canella, G. 1981. "Le componenti di un sistema integrato di servizi sociali metropolitani." In Introduzione alla cultura della città, ed. L. Meneghetti. Milan: CLUP.

Canella, G., M. Coppa, V. Gregotti, et al. 1968. Teoria della progettazione architettonica. With an introduction of G. Samonà. Bari: Dedalo, 1985.

Christofellis, A. 1976. Nel gran teatro dell'hinterland milanese: scuole materne come case del popolo. L'Architettura - cronache e storia 252, 294-307.

Guerzoni, G. 2008. Effetto Festival. L'impatto economico deifestival di approfondimento culturale. Milano: Fondazione Carispezia. https://www.festivaldellamente.it/wp-content/uploads/2015/07/allegato-1a-effettofestival083.pdf

Montuori, M. (ed.). 1988. Lezioni di progettazione. 10 maestri dell'architettura italiana. Milan: Electa.

Prandi, E. (ed.). 2012. CCA - Compact City Architecture. Historical City Centre Design in Europe. Parma: FAEdizioni.

Prandi, E. (ed.). 2013. Compact City Architecture. Designing Centrality, Regenerating the Suburbs. Parma: FAEdizioni.

Prandi, E. 2016. L'architettura della città lineare. Milan: FrancoAngeli.

Quintelli, C. 1989. La città del teatro. Seminario di progettazione architettonica. Milan: CLUP.

Quintelli, C. (ed.). 1995. La città del teatro: per una scuola di architettura: seminario di progettazione architettonica. Milan: Abitare Segesta cataloghi.

Quintelli, C. (ed.). 2000. CITTAEMILIA. Sperimentazioni architettoniche per un'idea di città. Milan: Abitare Segesta.

Quintelli, C. 2001. S.S.9 Via Emilia. Progetti architettonici e nuovi luoghi lungo la Via Emilia tra città e città. Milan: Abitare Segesta.

Quintelli, C. 2002. Il progetto CITTAEMILIA. Urbanistica Informazioni 186, 75-76.

Quintelli, C. 2005. La strada ritrovata. Problemi e prospettive dell'architettura della Via Emilia. Parma: FAEdizioni.

Quintelli, C. 2006. Il progetto della città contemporanea: riflessioni per un dibattito and Sette luoghi, una strada. Per una strategia di riqualificazione della via Emilia Est a Modena. In Città e progetto, ed. G. Villanti. Bologna: Editrice Compositori.

Quintelli, C. 2011. Cosa intendiamo per Food Valley? Parma: FAEdizioni

Quintelli, C. 2012. Cittaemilia: unico e molteplice in forma urbana lineare. In The Kent State Forum on the City CittaEmilia, ed. C. Quintelli and M. Sabini. Florence: Alinea.

Quintelli, C. 2014. Progettare il progettato: per una rinnovata centuriatio land nel contesto emiliano. In Paesaggi in trasformazione, ed. G. Bonini and C. Visentin. Bologna: Instituto Cervi - Biblioteca Archivio Emilio Sereni.

Quintelli, C. 2017. L’Università poleogenetica del progetto Mastercampus. In Paesaggio Urbano 1, $6-17$.

Quintelli, C. 2018. L'Abbazia archivio/museo/laboratorio. Un progetto architettonico per lo CSAC. Padua: Il Poligrafo.

Rogers, E. N. 1965. L’utopia della realtà: un esperimento didattico sulla tipologia della Scuola Primaria. Bari: Leonardo Da Vinci.

Rossi, A. (1966). The Architecture of the City. Padua: Marsilio. English translation (1982).

Tafuri, M. 1992. Ricerca del Rinascimento. Principi, città, architetti. Turin: Einaudi. 